\title{
Anthrovision
}

Vaneasa Online Journal

$6.1 \mid 2018$

Film in Ethnographic Exhibitions

\section{In Defence of Formal Experimentation:}

Reflections on the Dialogue Between Visual Aesthetics and Ethnographic Knowledge Through the Making of the Documentary Film Flyoverdelhi (2004).

\section{Paolo Favero}

\section{(2) OpenEdition}

\section{Journals}

Electronic version

URL: http://journals.openedition.org/anthrovision/3605

DOI: 10.4000/anthrovision.3605

ISSN: 2198-6754

\section{Publisher}

VANEASA - Visual Anthropology Network of European Association of Social Anthropologists

Electronic reference

Paolo Favero, «In Defence of Formal Experimentation: », Anthrovision [Online], 6.1 | 2018, Online since 31 December 2018, connection on 28 July 2019. URL : http://journals.openedition.org/ anthrovision/3605; DOI : 10.4000/anthrovision.3605

This text was automatically generated on 28 July 2019.

(c) Anthrovision 


\title{
In Defence of Formal Experimentation:
}

Reflections on the Dialogue Between Visual Aesthetics and Ethnographic Knowledge Through the Making of the Documentary Film Flyoverdelhi (2004).

\section{Paolo Favero}

\author{
"the penalty of realism \\ is that it is about reality \\ and has to bother forever \\ not about being 'beautiful' \\ but about being right" \\ John Grierson
}

\section{Epilogue}

1 Many years ago, during the Q \& A following a university screening of my 2004 film Flyoverdelhi ${ }^{1}$ (from here onwards FOD) I was asked by a senior colleague, who evidently had not enjoyed my film: "Why did you make an experimental film? Why should we as anthropologists experiment with art at all? What's the benefit?". What my colleague had reacted to were the stylistic choices that I, along with my co-director Angelo Fontana and editor Luca Gianfrancesco, had made when realizing this film. Offering glimpses into the lives of middle-class youths in New Delhi (India), FOD flirts in fact openly with the aesthetics of television, music-videos, advertisement and video-art. Addressing both laypeople and academics, the film breaks away from the stylistic choices that are conventionally associated with ethnographic film. I will soon unpack this concept further but let me for now only state, in likelihood with what Trinh T-Minh Ha suggested long ago, that ethnographic film has over the decades largely become associated with a particular set of stylistic choices that have progressively become taken-for-granted (and hence invisible) by practitioners and many viewers alike. The aesthetics of objectivity have, to paraphrase Minh-Ha, been mistaken for objectivity. Largely synonymous with 
what Nichols (2001) called the "observational" documentary mode, ethnographic films often upon: the invisibility of the image-maker; the lack of an explicit cinematic narrative (of a story so to say); the absence of photographic interventions and corrections; the use of directional microphone and lip-synchronous sound; the referral to real time (rather than filmic time) and hence the filming of long scenes and minimal or no editing; the absence of close ups (incapable of offering the context); the use of handheld cameras (giving a sense of authenticity to the viewer). With the exception perhaps of the handheld camera (that is used however in a significantly different manner, see below), FOD defies these tropes. The film is in fact characterized by intense editing. Wobbly images filmed á la MTV so-to-speak are glued together by a fast, intense and at times even invasive rhythm. The film contains separate narrative moments, each defined by a carefully constructed set of stories that run in parallel and often act in counterpoint to each other. It is also supported by an original musical soundtrack ${ }^{2}$ (a taboo in ethnographic film) that incorporates electronically re-elaborated sounds recorded by me in the streets of Delhi. This electronic music dialogues with visual effects (delays and echoes, enhancements and removals of saturation, etc.) and with elements of graphic design. All together these elements underline key passages in the film guiding the viewer in the act of taking possession of the film. With the exception of a few (poetic) phrases at the opening of the film, FOD has no voice-over. It therefore breaks also with another established "mode" of ethnographic film, the expository one, which has characterized the early days of ethnographic film and which still lives on in televised and pedagogical formats.

2 As I already announced I will soon discuss the categorization of ethnographic film in further detail. For now let me only point out how debates on ethnographic film often tend to be characterized by neglect of the epistemological consequences of the adoption of specific aesthetic and formal choices. Anthropology's prioritization of "anthropological relevance" on "aesthetic composition" (Wright 1998), has made its practitioners blind to the manifold ways in which visual form actually contributes to the creation of meaning and hence of knowledge. There is no content without form. As a member of several film festival juries, discussant and Q\&A moderator at screenings, examiner in a variety of different academic and film settings, let be active participant in presenting my own visual work in both academic and non-academic settings, I have with the years been given many opportunities to notice the reluctance of anthropologists to go in depth with matters of visual aesthetics. Discussions and evaluations tend to focus on what a film is about rather than on the film per se. The lack of attention and knowledge of many anthropologists for tools of film analysis adds to this incapacity to detect the extent to which form does in fact create content. I hence subscribe to Schneider and Wright's (2010) suggestion that the scene of contemporary anthropology is dominated by a "blanket condemnation of formally experimental visual and audio work" (p.3). They write:

"Anthropologists have for long been overly dismissive of formal experimentation not only in terms of expanding the range of methodologies and forms of presentation involved in exhibiting anthropological work, but also in the sense of 'policing' the kinds of work produced by research students" (Schneider and Wright 2010: 3).

3 This paper wants to draw the attention of the anthropological community to this dimension. Taking off from FOD but echoing broader debates on ethnography at large that may also echo the 1980's "writing culture" debate, I aim to raise questions about the meaning and role of aesthetics also in the anthropological practice. I claim that visual 
experimentation can on the one hand allow us to reach out to wider and more varied audiences (an important goal for many academics). But it can also allow us to rethink the conventional assumptions that sustain the production of ethnographic knowledge.

This paper will open up with a brief introduction aimed at contextualizing the ideas that informed the making of FOD and the debates regarding the meaning of "ethnographicness" (see Heider 1976) in the context of ethnographic film. I will then analyse four different aspects concerning the dialectic between form and content using FOD as my key example. The first topic addressed will be the role of verbalized narratives and of explanation. Taking off from FOD's opening scene, I will, in this section, discuss the meaning of voice-overs and of the dialogue between sound and text. The second section will address questions of ethnographic content in relation to mise en scène (i.e. the decisions regarding what appears before the camera) and camerawork (i.e. choices relating to how to film). The third section will focus on editing (a practice which underpins the act of writing too) as a conveyer of meaning. Finally, in the last section I will discuss the role of participatory approaches in the production of visible ethnographic material. Each of these four sections will be introduced by one selected scene of FOD that, exploiting the possibilities for publishing online, can be visualized by following the links appearing in the text. It is my hope that this paper will be able to stimulate reflection on the meaning of form and aesthetics in the production of ethnographic knowledge also beyond the limits of film and visual practices. Offering also a call for taking images and visual work "seriously", I will incite anthropologists to devote more attention to visual analysis as a way also to reframe established content- and text-centred analytical models.

\section{The Background}

FOD constituted a precious way for me to rethink the knowledge about Delhi's middle class youth that I had previously gathered through fieldwork. Between 1998 and 2001 I conducted research among that young, educated generation of middle class ${ }^{3}$ Delhi inhabitants that symbolized India's entry into the era of global economy (an entry formally sanctioned by the 1991 economic reforms). ${ }^{4}$ My interlocutors, who were all between twenty and thirty years of age, were enthusiastically using the opening up of India for personal purposes of career and leisure. With my research I explored the ways in which they experienced and constructed their identities vis-à-vis with the growing number of messages and images reaching the country from all over the world. The moment I captured with my research was one of intense growth in instances of pride in the country, an early description of the enthusiasm for a future 'Tiger India' (cf. Favero 2005 and Favero 2003). ${ }^{5}$ My fieldwork was very dynamic. I had to move between different work environments (tourism, the Internet, journalism, sports, multinationals, etc.) and also commute between different parts of the city. I also ended up spending endless hours hanging out with my interlocutors in public places in different neighbourhoods. This intensive exposure to the city's semiotic texture brought to my attention the correspondence between the intimate stories that I was collecting through my interlocutors and the visual and material texture of Delhi. Hanging around with these young men, I noticed how, for instance, the architecture, advertisement, design etc. were all underlying Indianness, hence mirroring the (and pushing for) growing instances of faith and pride in the Country. For my interlocutors, being 'cool', 'cosmopolitan' and 'modern' (terms adopted by them) was synonymous to being proudly 'Indian' and not 
something connected to 'Western' culture. Photography (and later on film) became fundamental tools for addressing this ongoing dialogue between the intimate and the public. I embraced visual media as a key tool in my research and I learned to playfully share with my interlocutors the act of image-making (something which also helped me in strengthening my bond with them). ${ }^{6}$ FOD was born along this stream of events.

Incorporating the experiences that I just described, FOD offers a series of overlapping snapshots of young Delhi' ites ${ }^{7}$ views over a changing India. The viewers are introduced to five leading characters: Neeraj (29, journalist), Rohit (29, manager), Jaidee (29, tennis coach), Puja (25, airline hostess), Anil (34, tourist guide) and Rummy (29, deejay). All such individuals represent careers that were boosted (or even really made possible) by the opening of India's economy to the global market. In line with my research, FOD offers to the viewers an insight into the lives of those young individuals who functioned as brokers of novelty for the country. In the film we are invited to take part at these characters' reflections on the historical phase they were going through. Neeraj, Rohit and company talk about globalization, about what modernity means to them, about love in times of great social changes, etc. We follow them in small moments of their daily life (in observational mode) and watch them converse either with each other or with an external interlocutor (in an interview mode). Alongside its five key characters, FOD introduces us also to a number of other young, selected protagonists as well as to some intellectuals. The young secondary characters speak about their experiences too while the intellectuals offer us a critical view (from above) on the topics addressed by the main characters in the film. All these conversations alternate also with long breaks in which we are invited to focus on a visual exploration of the city. Supported by a blend of music and diegetic sounds, these moments are functional for showing (and for further exploring) the varying ways in which the public visual culture of the city mirrors the stories that my interlocutors are sharing with us. The film is overall characterized by a multi-linear narrative structure. Through the help of cross-editing and other narrative strategies we are invited to explore all these stories and characters simultaneously. Even though the film opens up and ends with a night scene, FOD does not offer a linear experience of, say, one day in Delhi. Rather we are flirted in into what appears as a tentacular (for the viewer potentially challenging) narrative structure.

FOD is also influenced by notions of participation and co-creation. Loosely inspired by Rouche's "ethnofiction", I involved in fact my interlocutors in the choice of topics and situations to film. Asking them to "perform" themselves in front of the camera, we discussed almost every scene together often going back to re-interpret and at times (as in the scene with tourists below) to re-enact events that had happened during fieldwork (an indirect form of "visual elicitation", see Pauwels 2011). This approach allowed me to also gather new insights to the topics that I analysed in my book, in a process that lead me often to re-evaluate my previous interpretations. Simultaneously it constituted for me a way to challenge the conventional gaps that makes up ethnographic films and that Russell (1999), paraphrasing Minh-Ha, calls "a division of the world into those "out there" (the subjects of ethnography) and those "in here" (in the theatre, looking at them)" (p. 4).

Finally, let me also add that FOD grew out of a broader set of artistic experiences (starting from photography to video-installations, see Favero 2015) that I conducted between 1998 and 2004 and that were all centred around the desire to provoke Western views on India and 'other' postcolonial societies. With my work I wanted to unleash in my viewers a desire to participate in the 'world of others', and to close, through a number of 
provocations and inversions, the perceived gap between 'us' and 'them', between the socalled First and Third World. In more specific terms, I took off, in my work, with the idea of playfully challenging the hegemonic notions portraying India as the locus of prototypical alterity. The dominating ideas of India as a place of 'tradition' and 'contrasts', of 'spiritual purity and physical filth' (Khilnani 1997) were nothing but prolongations into the present of colonial tropes and divides. My interlocutors (in both fieldwork and film) were strongly reacting against such stereotypes. Incorporating their views, I decided to attempt to break such associations and 'force' the viewer, through the combined adoption of specific aesthetical stratagems and choices of content and through a strategic use of the spaces in which I exhibited my installations, to see India from a different angle. FOD was born along this stream of experiences. My approach to combining visual experimentation, postcolonial critique and participation/co-creation in the making of FOD constitute indeed an interesting terrain for looking further into the relationship between form and content. In order to address this topic I need to further reflect on the meaning of ethnography and "ethnographicness" in relation to ethnographic film.

Earlier attempts at defining the "ethnographicness" of ethnographic films have been characterized by a textual bias. Heider (1976) suggested that an ethnographic film must be about "whole bodies", "whole people", and "whole acts" (cf. Anderson 2003 and Banks 1992). For Fuchs (1988), instead, an ethnographic film must satisfy requirements of "unity of place, time, group, and action together with strict obedience to the chronology of action in the final version of the film. Artificial manipulation in either shooting or cutting is not permitted. A scientific film also rules out the use of staged scenes" (Fuchs in Banks 1992: 119). Goldschmidt (1972) suggested that "ethnographic film is a film which endeavours to interpret the behaviour of people of one culture to persons of another culture by using shots of people doing precisely what they would have been doing if the cameras were not present" (1972: 1).

If we were to follow such definitions, ethnographic films are those that, as Basu critically paraphrased it, "most closely replicate the 'scientific enterprise' of ethnographic research and writing" (2008. 95). Indeed, such approaches are today in evident need of critical reflection. In the first place, as Banks suggested in his seminal 1992 paper, we must acknowledge that these notions are informed by an underlying (a-critical) idea regarding the nature of film as a process of simple encoding of "'reality' directly upon the film strip" (Banks 1992: 118). Ethnographic filmmakers uphold, in other words, a difference between filming as documentation of research and filming as cinema, strictly giving priority to the former and marginalizing the latter. For such reasons, Banks suggests, they look upon any cinematographic intervention (such as "good shots, exciting cutting, the division of material to allow for commercial breaks, strong narrative content, engaging personalities", 1992: 118) as intrusions that "may obscure the ethnographic criterion" (1992: 118). Secondly, positions as those expressed above are neglectful of the role of the audience in the shaping of the ethnographic meaning of a film. As Basu suggested, ethnographic film largely appears as a "genre in search of an audience" (2008:103). Little attention has conventionally been paid in this context to the dialogues and negotiations of meaning taking place between filmmakers, their films and their viewers. As Bruzzi reminds us, however, any documentary film "is a negotiation between reality on the one hand and image, interpretation and bias on the other" (2006:6). Following such ideas, the "ethnographicness" (Heider 1976) of a film cannot exclusively 
reside in the images (which is the assumption that underlines the approaches of the above-mentioned theorists). Rather it emerges out of a wider conversation with the audiences. Banks (1992) suggests that the ethnographicness of a film is to be found in the spaces of "intention", "event" and "reaction". We must, taking on from his suggestion, involve in our analysis not only the views, intentions and knowledge of the author, but also the modalities of production of a film, i.e. the varying ways in which the characters represented in the film are engaged, their desires in relation to the film and their agency in the very making of it. And we must also include a careful analysis of the contextual dialogues taking place with the film's various audiences and venues of distribution. Following such reflections, we must perhaps, paraphrasing Eitzen (1995), ask ourselves not "what" but rather "when" is an ethnographic film.

The shift of attention away from the explicit content of the film to the negotiation of meaning generated in the dialogue with the spectators brings indeed the question of form and aesthetics back to the center of our attention. In 1991 Sanjek suggested that any piece of anthropological work (no matter whether visual or written) is composed by two separate (but dialoguing) aspects, i.e. by "ethnographic validity" and "ethnographic authority" (1991). The former refers to principles of theoretical transparency, of methodological rigor and of continuity between the raw material (field notes, raw footage) and the end product (be it a text, a film etc.). The latter instead relates to the capacity of an author to convince her or his reader/viewer/listener about the thesis put forth and is therefore based on the aesthetic, formal, rhetorical choices made for constructing a convincing argument. Sanjek insists that any ethnographic work is the result of a dialectic between these two aspects, i.e. between validity and authority. These can never be kept apart from each other. Ricoeur too (1986) has commented upon this question with regards to text in general. According to him, knowledge allows itself to be communicated only through a process of 'textualization', and hence through authorial choices which are indeed a matter of form (cf. also Foucault 1977). Following Sanjek and Ricoeur we cannot but approach aesthetical and formal choices, therefore, as part and parcel of the creation and communication of ethnographic knowledge. Using Wright's (1998) terms again, "anthropological content" and "aesthetic composition" do always dialogue with each other, penetrating each other to the extent that we cannot keep them apart. Form is, in other words, always also content and the other way around is always true as well.

In the case of film, the role of form in shaping up content can be identified in different ways. The choice of, for instance, a short lens instead of a long one, of deep or shallow focus $^{8}$, of a close up or a medium shot, etc. do contribute in conveying a particular meaning and, hence, "content" to a scene (that the viewer will then eventually be asked to interpret). In the case of FOD authorship is made visible, for instance, through the specific choices of editing, camerawork, in the dialogue between images and sound etc. While not being physically visible in the film, my presence in FOD is felt at the level of all these choices. Ethnographic filmmakers and anthropologists learn, however, conventionally to conceal the meaning of these aesthetic choices under a cover of naturalness and objectivity. And, as I mentioned above, they also marginalize this discussion altogether by keeping distance from the tools of film analysis and film theory (which are fundamental to uncover visual stylistic choices). As I anticipated above Minh$\mathrm{Ha}$ (1990) has suggested that ethnographic films promote "objectivity" through a series of stylistic choices. Corresponding to the employment of specific technologies (such as the 
use of directional microphones, of handheld cameras, etc.) such choices produce an "aesthetic of objectivity" (1990:80) that is erroneously commonly interpreted as "objectivity". However, as we know, the material of films is always cooked and never raw (see Anderson 2003). As Bazin (1967) stated long ago realism "can only be achieved in one way-through artifice. Every form of aesthetic must necessarily choose between what is worth preserving and what should be discarded, and what should not even be considered" (p. 26).

Having delineated this background let me now proceed to concretize my reflections with the help of a number of selected scenes from FOD.

On voice and sound - the intro

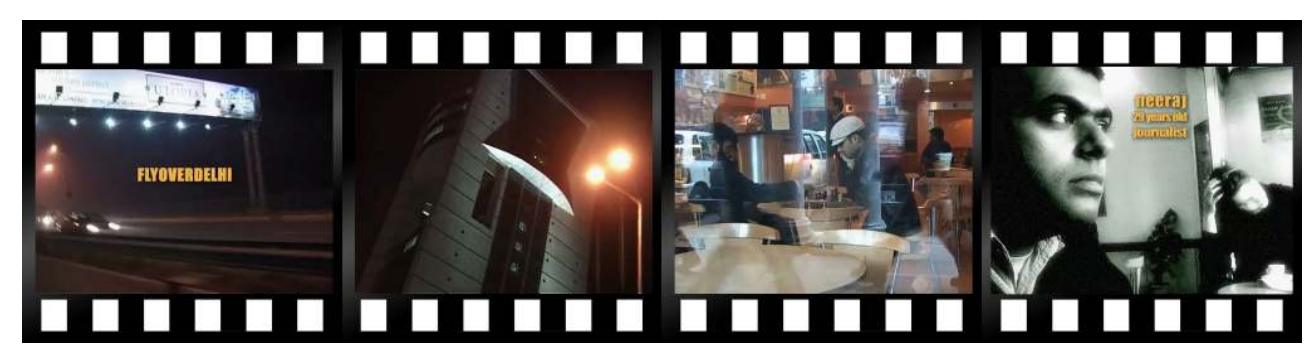

Photo montage by: Paolo Favero

This media file cannot be displayed. Please refer to the online document http:// journals.openedition.org/anthrovision/3605

Video link: https://vimeo.com/76251870

The opening scene immediately displays one key characteristic of FOD, i.e. its approach to voice-over and sound. Overall, with the exception of the first seconds, the film lacks a verbalized, extra-diegetic voice-over, and hence an authoritative textual explanation. Yet, it is full of verbalized reflections by its key characters. The absence of a voice-over gives the film also a somewhat different character to many (explanatory) documentaries. Functioning, to use Barthes' (1997) terms as a form of "anchoring", voice-overs are in fact often used by ethnographic filmmakers for allowing them to exercise a degree of control over the construction of meaning. Doing this however, directors cage images' intrinsic polysemy hence removing from a film its potential to generate open-ended associations. ${ }^{9}$ With its lack of voice-over, FOD was designed to provoke this habit. It aimed at bringing back to the centre of our practice an attention to images' capacity to escape our control and to ignite unexpected associations and reflections, something that, as MacDougall (1998) has showed, is of fundamental importance in a transcultural setting and that can be looked upon as one signifier of the risk for it to become art.

Indeed, despite the overall absence of voice-over, FOD does, as I anticipated, contain many verbalized narratives. As I mentioned above, the film's main characters do speak out loud their reflections and views. Their talking has, however, in the general economy of the film, different meanings. On one level it functions per se as a metaphor of globalization. The key characters' endless chatting about globalization shows how, in the context of their life-worlds, globalization is debated through slogans, mottos, words and in particular though the evocation of "phantasms"10 (cf. Favero 2003 and 2005), i.e. of abstract notions of India and West, of modernity and tradition. Such debating is also, as I 
will discuss in greater detail below, made up by a large amount of overlaps and contradictions (yet another metaphor of globalization). The actors' talks however, have another function too. They do indeed provide an understanding of the film characters' own (emic) ways of conceptualizing their lives, their city, country and epoch. In line with the principles of ethnography we hence get insights into the categories though which they understand their lives and life-worlds. This too happens however without the need of a voice-over interpreting such exchanges. The duty to interpret their descriptions is left to the viewer. A small help in that direction is however given by the commentaries offered by a few selected Delhi-based intellectuals. Sociologist Dipankar Gupta, writer/ diplomat Pavan Varma, writer/activist Urvashi Butalia and media-scholar Babbli Saraf share with the viewer their critical insights on the topics addressed (or lived) by the characters of the films hence helping the viewers to identify larger narratives of cultural change.

This media file cannot be displayed. Please refer to the online document http:// journals.openedition.org/anthrovision/3605

Video link: https://vimeo.com/31143151

Marking out visually the difference between their voices and the voice of the key characters of the film, these short interventions are introduced by an audio-visual jingle and shown in de-saturated colours (appearing almost like a black-and white). They are filmed on a tripod and from a longer distance so that the quality of the sound is also markedly different. Basically they "pop-up" like short television ads or hypertextual links and take the viewer into a different audio-visual space altogether.

Overall, the opening scene of FOD is indeed indebted to other works and in particular to Robert Gardner's Forest of Bliss. In the opening of this film, Gardner offers us a series of impressionistic glimpses remanding to the four elements and hence to the principles of the Vedas (cf. Gardner and Ostor 2001). Such images are commented by one single quote from the Upanishads (via W. B. Yeats): "Everything in this world is eater or eaten. The seed is food and the fire is eater". While offering a lead, introducing the viewers to the key topic of the film, this scene does not, however, in coherence with the rest of the film, really explain what the viewers see. Yet it draws attention, albeit in a poetic manner, to one central theme in the film leaving then the rest of the interpretive labour in the hands of the viewer. In fact, only the cinephile or the Indophile may perhaps really understand all the messages hiding behind the surface of Forest of Bliss. Nonetheless, the viewers are challenged (in a very respectful manner indeed) to enquire further into the meaning of the experiences and practices that they are viewing.

\section{On Camerawork and Metaphors - The Camera Car}

Let me now address another aspect capable of showing the dialectic between form and content. Amidst what is undoubtedly a fairly dense structure of intense exchanges of opinions by the films' main characters, FOD offers also moments of audio-visual contemplation. The majority of these moments are made up of camera cars (i.e. of images taken from a moving car), but other forms of visual exploration of the city's visual and material culture (such as pans, stills, etc.) are also adopted. Let me discuss these passages with the help of another sequence. 


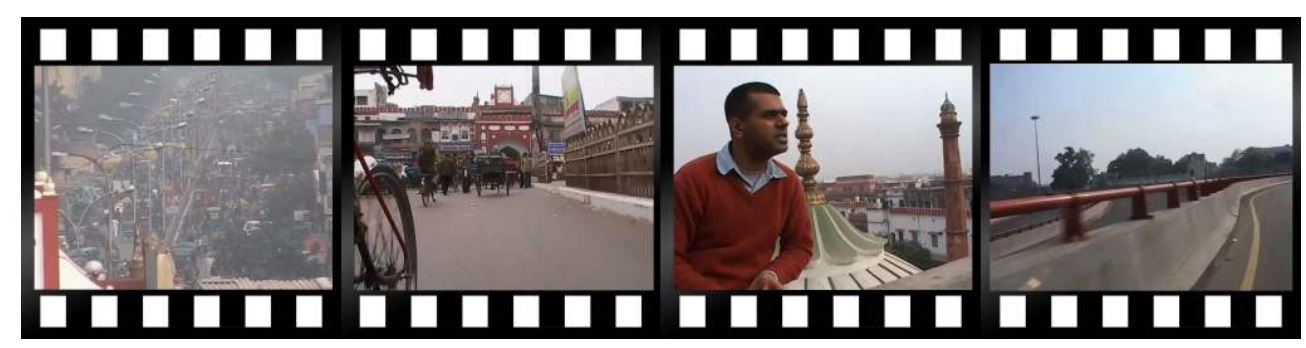

Photo montage by: Paolo Favero

This media file cannot be displayed. Please refer to the online document http://

Passages such as the one contained in this clip, so we hoped while making the film at least, would permit the viewers to take a break from the dense narrative that dominates the film while providing them also with an opportunity to enact an audio-visual exploration of the city. Addressing the city's public façade as an "urban gallery" (Bhatia 1994:32) capable of displaying varying narratives of cultural change, these sequences are indeed underpinned by ethnographic knowledge. In the first place, they offer a series of parallels between the stories shared with us by the characters of the film and the city in which they live, hence permitting us to better understand their experiences. As I explained above, this choice reflects indeed my intent to explore the way in which social actors' views and experiences are shaped in an ongoing dialectic with wider cultural flows that can be detected in the visual and material culture of the city. Secondly, such passages are also functional to materialize, once again, my interlocutors' abstract notions (their "phantasms") of India, West, modernity, tradition, which appear in the urban landscape in the shape of signs, buildings, posters, etc. These seemingly relaxing and entertaining scenes offer hence the viewers another (non-verbalized) opportunity to understand my interlocutors' ways of addressing, adapting to and shaping cultural change, hence bringing them in touch with theoretical insights regarding social and cultural change in Delhi again, without having to recur to the use of textualized voiceover explanations.

Camera work and choices of mise-en-scene are fundamental for understanding the extent to which visual form can help us metaphorizing ethnographic insights. The choice of setting a large number of scenes of FOD in cars (a choice of mise-en-scene) symbolizes, for instance, another aspect related to my understanding of the lifestyle of the young men and women that are at the centre of the film. The characters in FOD, in fact, spend most of their days in cars. They have to spend hours daily defying the traffic of this boosting city in order to go to work, to meet their friends, to go and watch a movie, etc. Car rides are therefore moments in which memories are shared, secrets revealed, business plans drafted and so on. They are hence proper metaphors of middle-class life in Delhi. ${ }^{11}$ Yet, instead of verbalizing such a statement (e.g. through a voice-over) FOD lets the viewers infer this through the choice of staging and camerawork. It is also in (and through) a car that the encounter between the key actors of the film and urban poverty takes place. The 
critical distance between these two worlds is portrayed with the help of a few voyeuristic shots of beggars filmed from behind the window of a car (see the picture below).

Critical distance

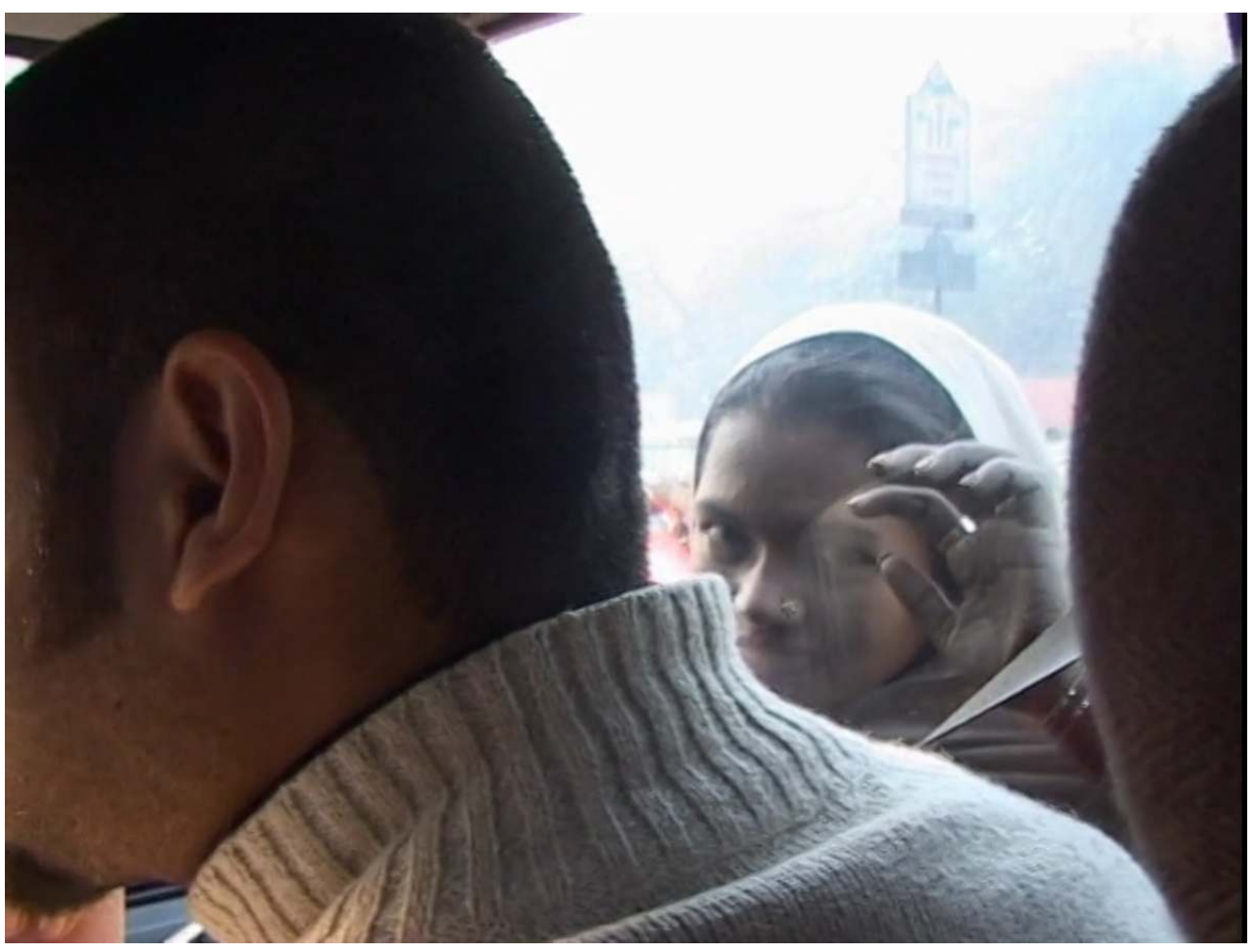

Still frame from Flyoverdelhi (Favero and Fontana)

The presence of car rides combined with the many scenes of busy metropolitan street life, are also part of a wider reflection relating to the specific moment in Indian history in which the film was made. In order to invite the viewer to approach India as a country involved in a process of globalization, FOD pushes in fact to the fore the viewers' potential associations between "globalization" and notions of speed, acceleration, fragmentation, overlap etc. i.e. with the conventional tropes that have been used to characterize this phenomenon (cf. MacQuire 1998). Such association is indeed strengthened by the specific type of camera work adopted. One of the first things that viewers have to get used to in FOD is, as I mentioned above, the presence of a hand-held, moving and "wobbly" camera ${ }^{12}$ . With the only exception of the interviews with the intellectuals (that are, in order to mark out a difference in voice, steadily filmed with a tripod) the film builds upon images created with a camera constantly "waving" around the actors, building circles in the air, zooming in and out, containing a lot of canted framings in a style which a Swedish film critic mockingly defined "MTV-style". Editing (which I will discuss further in the next section) and music have indeed been fundamental too for underlining this association. With its speed and playfulness, with its intensive use of graphic insertions and cover shots, editing strengthens the association with the language of global youth culture. And the music does so too with its contemporary, electronic character. Combined together, camera work, editing and music end up producing aesthetic associations with the language of globalization and in particular of globalized youth culture. The parallel with MTV is hence not far-fetched. The visual language of FOD echoes with that conventionally adopted during those days by this international music channel (it is therefore that I 
actually experienced the journalist's mock actually as a compliment). And it is not coincidental that the generation under scrutiny in FOD is conventionally referred to as the "MTV-generation"13.

Such associations are, as an add-on, also meant to trigger off transcultural associations and to make the viewers reflect upon the meaning of globalization at large. As I could observe during the many Q\&A's following the screenings of the film that I held in particular in 2004 and 2005, this kind of reflections were often triggered off in the viewers by the film. To mention but a few, in Lund, Sweden, a student provocatively asked me after the screening why I had decided to go all the way to India to document a phenomenon that was so visible in Sweden too. Similarly, in Asti, Italy at a multicultural festival, one young man told me, with a visible expression of delusion painted on his face: "It's such a pity! I always wanted to go to India but if it's like this...well, then there's no point!".

On editing and narrative - talking about love

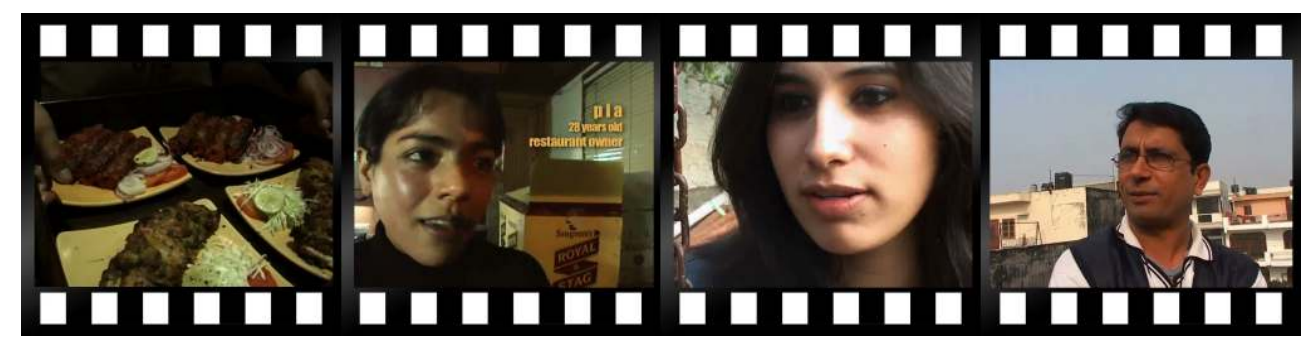

PHOTO MONTAgE BY: PAOLO FAVERO

This media file cannot be displayed. Please refer to the online document http://

Video link: https://vimeo.com/76251790

The narrative contained in this clip, which results out of the act of bringing in touch with each other conversations that took place in different moments and places, has been made possible by the use of cross-editing. Also known as parallel-editing, this technique allows to bring in dialogue events that are pro-filmically (i.e. in "real" life) disconnected from each other. In this specific case Puja, Pia and Anil are conversing with me separately. Actually, they may not even know each other. Cross-editing is here functional for bringing to the surface the manifold contradictions and tensions that surround the debate on gender, love and marriage in the context of a globalizing India. Resulting out of the construction of a proper narrative puzzle (which took us quite some time to put together) this technique allows also to add a certain humorous touch to the sequence. I have conventionally witnessed to audiences laughing at the contradictions expressed by Pia's, Anil's and Puja's overlapping monologues.

Overall the use of montage (rather than of continuity editing), allowed me to offer a critical point of view on the discourse on globalization that characterized Delhi's middle and upper classes during those days. As the dialogues between Puja, Pia and Anil show, globalization results at a local level in a series of contradictory slogans (I already hinted at this aspect above). This is evident in the sentences pronounced by Puja (who states within the same conversation that women are beating men in all fields but then also that 
they have to become mothers to their husbands) and in the evident tension between her words and those of Anil (who claims that Indian women only dress up as emancipated characters but are really traditional at heart). Such conversations open hence up a space of reflection on gender in a globalizing India and bring to the fore the absence of a coherent narrative regarding the ways in which globalization is contributing to create social change. Globalization appears here almost as a terrain in which a semiotic battle for gender emancipation, upward class mobility etc. are being fought. And such battles are fought by evoking "phantasms" of modernity and tradition, past and present. Crosscutting allows to reveal the frail, emotional and shifting character of these notions and debates. It helps bringing to the surface the overall contradictions that characterize social actors' multiple ways of experiencing their gender and sexuality in times of great cultural change. In a way this constitutes another way of addressing the "parallax effect" that Ginsberg (1995) addresses when discussing the ways in which the incorporation of indigenous voices can allow for the creation of multiple perspectives.

Overall, the narrative structure of FOD can, as I hinted at in the introduction, probably be defined multi-linear. Rather than following a linear time-based sequence of events, viewers are asked to follow a number of topics across a multiplicity of overlaps, parallel situations and space and time disjunctures. Following the principles of what may be labelled as "thematic cutting" (Giannetti 2008), FOD constitutes, in a way, also a flirt with hypertextual structuring. In the film in fact, one specific reflection by one of the characters leads to another reflection on the same topic by another character and so on. The topics addressed take in this way control over the plot, forcing the viewer to abandon the need for time and space coherence or also for focussing on one specific character at a time. This structure is indeed the result of an implicit dialogue with another visual language that exercised a great influence upon me, i.e. video-installation. For FOD I played with the idea of letting ethnographic film dialogue with this artistic practice. I considered in fact using the same material to generate an (inter)active exhibition. I wanted to let different thematically defined chapters run contemporaneously in different corners of a room and have viewers construct their own narratives by moving from one screen to another. I also considered pushing this further and develop an online interactive platform based on a map of Delhi containing moving and still images, sounds and texts. Indeed, in 2004 the technologies for realizing interactive documentaries were not fully developed yet. ${ }^{14}$ To realize such a project would have required much more technical skills than I possessed or would have been able to afford. So, without ever going that direction, FOD contains, however, elements of this logic. The film constitutes, through its multilinear structure, an attempt at challenging viewers to construct their meaning as they proceed in the exploration of the materials on which the film is based. It also constitutes an attempt at finding a language capable of rendering the overlapping, disjointed and seemingly contradictory experiences that characterize the life-world of the actors in the film. Let me now address a final aspect of FOD with the help of one last scene. ${ }^{15}$ 


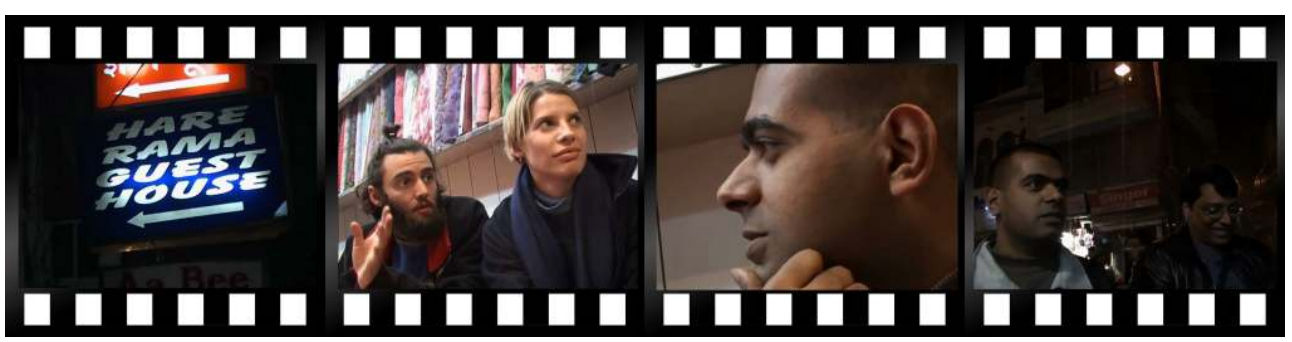

PHOTO MONTAgE BY: PAOLO FAVERO

This media file cannot be displayed. Please refer to the online document http://

Video link: https://vimeo.com/31144677

31 The sequence in the clip above is the result of a participated, coordinated and playful effort. As I mentioned earlier on in this paper, Rohit, Neeraj and the other characters of FOD, have been actively involved in the design of the film, in the choice of topics to address and characters to include. The involvement of Puja and Pia (see above) is one natural outcome of such process. Originally, I had, for instance, not even considered the possibility of including women in the film. I wanted to focus on the topics that characterized my fieldwork (masculinity being one key topic) and hence work exclusively with young male interlocutors. Yet, my conversations with Rohit, Neeraj and company lead me to change my views. And the reasons behind some of these changes were in some cases quite serendipitous and funny. One of the first female characters involved was for instance inserted in the film upon request of one of my main actors. Having developed a fling for this woman, this young man envisioned the film as a nice opportunity for getting closer to her. Indeed, I could not but open up the film to these new events, including them as proper ethnographic events, and use them as precious opportunities to rethink the topics that I had previously addressed through my research. The Pahar Ganj scene too is the result of such a negotiation between me and my interlocutors. It is also the result of a dialectic between present and past, bordering to what is conventionally referred to as re-enactment (i.e. the acting out of an event that really happened in the past). In 2000, I had, in fact, taken Rohit and Neeraj to Pahar Ganj to interview tourists. I wanted to experiment with this modality for the purpose of rethinking my notions of Western tourists' idealizations of India and to explore, at the same time, my interlocutors' reactions to such stereotypical visions. We went to the popular Hare Rama guesthouse's roof top restaurant and had a drink. On that occasion no one wanted to be interviewed by us but we managed in any case to capture precious gossips about India aired by the people sitting around us. Sweeping idealizations were made regarding Indian spirituality and culture. Delhi was looked upon as a fake place, one lacking in Indianess, while places like Varanasi and Kolkata (back then Calcutta) were idealized as true representatives of India. Following our snack on the rooftop Rohit, Neeraj and I spent the evening walking around Pahar Ganj, chatting about tourists' representations of India and so forth. On that occasion Neeraj and Rohit started making fun of Westerners' superficial view of India. For FOD I just shared with them my memory of that event and, with the help of the first tourists we found we re-lived (almost re-enacted) that moment. Paradoxically the tourists 
we encountered this time were not only humanly generous with us but they actually fed us exactly the same topics as the previous ones that we had overheard on the rooftop. I cannot hide that I was very content with the outcome of this event.

As may be evident from the lines above, the making of FOD was informed by an approach to the act of filmmaking as a performative event (cf. Bruzzi 2006). ${ }^{16}$ In my practice (as well as in my teachings) I have tended to push this aspect quite far, addressing filmmaking as a playful moment of sharing and bonding. As a teacher, I conventionally ask my students to move away from standard metaphors of "shooting" or "capturing" an event. Instead I ask them to enter a much more uncertain terrain. Inviting them to visualize the camera as a kind of connector between them and subjects they would never meet in the absence of this device, I attempt at making them focus on the exchange per se rather than on its outcome. Using a somewhat similar approach FOD is however also informed by another modality of engagement, i.e. by some of the principles characterizing ethnoficition (Stoller 1992, Himpele and Ginsburg 2005). Similarly to what Jean Rouch did, for instance, in Chronique d'un été (1960) or La Pyramide Humaine (1961), I asked our interlocutors to "act themselves" in front of the camera, i.e. to use the camera for sharing their own story and their own visions of themselves. According to such ideas I invited my interlocutors to have fun with the film, to make new things happen through it. The result was from this point of view indeed pretty astonishing. Neeraj who had just come back from England where he had been awarded an MA in journalism, was, I believe, quite keen in displaying his new cosmopolitan identity. Jaidee would proudly insert in the film gazes into his newly started tennis academy and "use" the film to present an achievement that had been the result of several years of work. Anil, coherent with his conventional way of being, enjoyed using the camera for decentring conventional notions of cosmopolitanism. Speaking Italian rather than English in moments he defied the Indian middle and upper classes conventional Anglocentrism. And finally Rohit, would, in accordance with his overall attitudes, simply enjoy the moment and fill our footage with witty jokes, smiles and an overall positive energy.

During one of my visits to Delhi, in January 2014, I discussed the film with my old interlocutors in the light of the 10 years that had passed since its making. I was surprised to notice how all my interlocutors wished I made another chapter, a 'ten years later' version. Among them, Jaidee forced me to carry the camera to his 40th birthday. Given that I filmed FOD exactly during the time in which he turned 30, he felt that my filming was a precious diary allowing him to keep track of his own life trajectory. Similarly, Rohit pointed out how FOD made visible the change that has happened in the country. In 2004 everyone one was dreaming of India becoming a superpower while today those dreams have been broken and a deep crisis has taken over the country. Playing with the film's original title he suggested that the new episode should be called "CrashingDelhi". Indeed, the playfulness that characterizes FOD (as well as my present exchanges with its main actors) depends upon the high degree of intimacy between us. At the time of filming FOD I had known these individuals for at least six to seven years and today we have known each other for more than a decade and a half. The intimacy of a long-term relationship gives indeed a number of privileges in the context of documentary filmmaking.

The combination of stylistic choices and mode of production (that is the strategies of engagement and negotiation of meaning with the participants) that characterize FOD constitute indeed an ongoing provocation to the notions of realism on which documentary film in general (and ethnographic film in particular) are funded. The spell 
of realism in FOD is broken right in the very beginning of the film. As the reader may remember, the first person we encounter in the film, Neeraj, the journalist, takes us for a walk in CP. During this promenade, after having allowed the camera to follow him as he walks along the colonnades, stops to purchases a magazine etc., Neeraj suddenly starts looking directly into the camera. Explicitly interpellating the viewers, he invites them to come and discover the city with him and his friends. This rhetorical stratagem removes right from the beginning the distance between "the staging of a representation and its maker or metteur in scene" (Nichols 1991:34), breaking down the space "between the world represented and the viewer" (1991:34). Neeraj's consistent gazing into the camera and his interpellation of the viewer interrupt the reassuring mechanism on which observational stances and feelings of realism are built upon (cf. Nichols 1991). Playfully bringing us into the scene and in touch with one of its main characters right from the beginning, FOD forces us therefore to bend our conventional expectations of realism when viewing ethnographic films and to enact a critical rethinking of the conventions on which this particular genre relies upon. I will further discuss this question in the following, conclusive, reflections.

\section{Conclusions}

With the help of FOD I have in this paper tried to show the fundamental role played by visual form and aesthetics in the creation and communication of ethnographic knowledge. In the making of this film, I let the choices of style dialogue with the content of the film. Such a playful engagement allowed me simultaneously to reach out to broader audiences and to close the gap between me and my interlocutors. It also triggered off a critical rethinking of what it means to make films and ethnography in a postcolonial world. My work on FOD attempts to live up to the task of postcolonial ethnography which, as Catherine Russell suggests, "is not only to include the Other within modernity but to revise the terms of realist representation" (1999: 6).

It is important to stress that form or style should, in the context of ethnographic film, not be looked upon as the possession or trademark of the individual filmmaker. The style of FOD for instance is not "my style" but rather a form that emerged in the act of making the film and that proved to be instrumental for the successful exploration of the particular topics and context addressed by the film. Form is, with regards to ethnographic practice, something emerging in dialogue with the field, in the exploration of a particular topic, place or group of people. It is not an a priori choice but the sum total of the negotiations enacted with the crew, with the actors involved, with the visual and material culture of the venues in which a film is made and with the viewers. I envision ethnographic film to be the result of a collaborative, choreutic dialogue between all these different actors. According to this view, meaning emerges in performance and knowledge appears to be a 'processual aspect of human social relations' (Banks 2001: 112) rather than as a static thing 'out there' waiting to be discovered and 'documented'. This forces us hence to move away from ready-made and solidified ideas of "authenticity" that, as I mentioned in the introduction to this text, tend to create a gap between here and there, Self and Other. Today, more than ever we must find ways to move beyond the conventional equation between ethnographic film and "the history of the production of Otherness" (Russell 1999: 10) My hope in the making of FOD was that the use of fragmentation and contradiction (combined with the other stylistic choices) may invite 
the viewers to enter a dynamic process of meaning-making with the film, hence allowing the latter to function as "a kind of laboratory in which the politics of representation and the conventions of observational cinema are being brought under scrutiny" (1999: xii).

Experimenting with visual form can help anthropologists gain further insights into the dynamics and politics of construction and communication of ethnographic knowledge also beyond the terrain of film and visual practices. A precious antidote to the idea that ethnography is, as Jay Ruby suggested long ago, a style that ethnographers acquire "in graduate school, in the field, and at professional meetings" (Ruby 1975:105) we are here offered an opportunity to enlarge our perception regarding what ethnography is including, and I paraphrase Russell again, not only "the representation of other cultures" but also "the discourse of culture in representation" (1999: xvii). Nichols (1994) too has suggested that experimental film can bring to the fore the idea of film as "cultural representation" rather than as a "representation of culture". This is what formal experimentation helps bringing to the surface. Regardless of whether we engage the world by means of a camera or a notepad, form is always one of the pillars on which we construct ethnographic knowledge and we need to develop skills to understand its manifold dialogues with content. As I mentioned at the beginning of this text, ethnography is always constructed around the dialogue between validity and authority and we have to learn envisioning it as "an experimental practice in which aesthetics and cultural theory are combined in a constantly evolving formal combination" (Russell 1999:14).

\section{BIBLIOGRAPHY}

\section{Books and articles}

Agamben G. 1993. Stanzas: Word and Phantasm in Western Culture. Minneapolis: University of Minnesota Press.

Anderson, K. T. 2003. Toward and Anarchy of Imagery: Questioning the Categorization of Films as Ethnographic. Journal of Film and Video, 55 (2/3): 73-88.

Banks, M. 1992. 'Which films are the ethnographic films?', In Film as Ethnography., P. I. Crawford and D. Turton, eds. Pp. 116-29. Manchester: Manchester University Press in association with the Granada Centre for Visual Anthropology.

Banks M. 2001. Visual Methods in Social Research. London: Sage.

Barthes. R. 1977. Image Music Text. London: Fontana Press.

Basu, P. 2008. Reframing Ethnographic Film In: Rethinking Documentary: New Perspectives, New Practices. Thomas Austin and Wilma de Jong, eds. New York: McGraw-Hill/Open University Press. Bazin, A. [1945] 1967. An Aesthetic of Reality: Cinematic Realism and the Italian School of the Liberation. In What is Cinema? Volume 2. A. Bazin and H. Gray. eds. Pp. 16-40. Berkeley and Los Angeles: University of California Press.

Bhatia, G. 1994. Punjabi Baroque and Other Memories of Architecture. New York: Penguin. 
Bruzzi, S. 2006. New Documentary. London: Routledge.

Eitzen, D. 1995. When Is a Documentary?: Documentary as a Mode of Reception. Cinema Journal. 35 (1): 81-102.

Favero, P. 2003. Phantasms in a 'Starry' Place: Space and Identification in a Central New Delhi Market. Cultural Anthropology 18 (4): 551-584.

Favero, P. 2005. India Dreams: Cultural Identity Among Young Middle Class Men in New Delhi. Stockholm Studies in Social Anthropology Vol. 56.

Favero, P. 2013. Getting Our Hands Dirty (Again): Interactive Documentaries and the Meaning of Images in the Digital Age. Journal of Material Culture. 18 (3) :259-277.

Favero, P. 2015. For a Creative Anthropological Image-making: Reflections on Aesthetics, Relationality, Spectatorship and Knowledge in the Context of Visual Ethnographic Work in New Delhi, India. In: Media Anthropology and Public Engagement. S Abraham and S. Pink, eds. Pp. 67-91. Oxford: Berghahn.

Foucault, M. 1977. What is an Author? In Language, Counter-Memory, Practice. Michel Foucault. Pp 124-127. Ithaca, New York: Cornell University Press.

Fuchs, P. 1988. Ethnographic Film in Germany: An Introduction. Visual Anthropology 1: 217-233.

Gardner, R. and A. Ostor. 2001. Making Forest of Bliss. Intention, Circumstance, and Chance in Nonfiction Film. Cambridge: Harvard University Press.

Giannetti, L. 2008. Understanding Movies. NJ: Case Western Reserve University.

Ginsberg, F. 1995. The Parallax Effect: The Impact of Aboriginal Media on Ethnographic Film. Visual Anthropology Review 11 (2) (fall 1995): 64-76.

Goldschmidt, W. 1972. Ethnographic Film: Definition and Exegesis. PIEF Newsletter 3 (2): 1-3.

Gupta, D. 2009. The Caged Phoenix: Can India Fly? Stanford: Stanford University Press.

Heider, K. G. 1976. Ethnographic Film. Austin, Texas: Univ. of Texas Press.

Himpele, J. and F. Ginsburg. 2005. Cine-trance: A Tribute to Jean Rouch (1917-2004). American Anthropologist 107 (1): 108.

Ivy M. 1995. Discourses of the Vanishing: Modernity, Phantasm, Japan. Chicago: University Of Chicago Press.

Kamdar, M. 2007. Planet India. The Turbulent Rise of the Largest Democracy and the Future of Our World. London: Simon \& Schuster.

Khilnani, Sunil 1997. The Idea of India. New York: Farrar Straus Giroux

MacDougall, D. 1998. Transcultural Cinema. Princeton: Princeton University Press.

McQuire, S. 1998. Visions of Modernity: Representation, Memory, Time and Space in the Age of the Camera. London: Sage.

Minh Ha, T. T. 1990. Documentary Is/Not a Name. October 52 (Spring): 76-98

Nichols, B. 1991. The Ethnographer's Tale. Visual Anthropology Review 7 (2): 31-47.

Nichols,B. 1994. Blurred Boundaries: Questions of Meaning in Contemporary Culture. Bloomington: Indiana University Press. Pp 17-42.

Nichols, B. 2001. Introduction to Documentary. Bloomington: Indiana University Press. 
Pauwels, Luc 2011. An Integrated Conceptual Framework for Visual Social Research. In The SAGE Handbook of Visual Research Methods E. Margolis and L. Pauwels, eds. Pp.3-23. Los Angeles, London: Sage.

Ricoeur, P. 1986. Tempo e Racconto. Milano: Jaca Book.

Ruby, J. 1975. Is An Ethnographic Film A Filmic Ethnography? Studies in the Anthropology of Visual Communication 2 (2), Fall.

Russell, C. 1999. Experimental Ethnography: the Work of Film in the Age of Video. Durham, London: Duke University Press.

Sanjek, R. 1991. The Ethnographic Present. Man 26(4): 609-628.

Schneider, A. and C. Wright. 2010. Between Anthropology and Art: Contemporary Ethnographic Practice . Oxford: Berg.

Stoller, Paul. 1992. The Cinematic Griot: The Ethnography of Jean Rouch. Chicago: University of Chicago Press.

Taroor, S. 2007. The Elephant, The Tiger, and the Cellphone. Delhi: Penguin, Viking.

Wright, C. 1998. The Third Subject: Perspectives on Visual Anthropology. Anthropology Today 14

(4): 16-22.

Films

Gardner, R., dir. 1986. Forest of Bliss.

Morin, E. and J. Rouch, dir. 1960. Chronique d'un été.

Rouch, J., dir. 1961. La Pyramide Humaine.

\section{NOTES}

1. Year: 2004. Length: 53 min. Author: Paolo Favero, Directors: Paolo Favero and Angelo Fontana, Editing: Luca Gianfrancesco, Original Soundtrack: Fabrizio de Piccoli, Production: Paolo Favero with funding from Swedish Bank of State's Tercentenary Fund and Helge Ax:son Johnsons Foundation, Stockholm.

2. The soundtrack is composed and played by electronic musician Fabrizio de Piccoli.

3. In my writings on this subject I have used the label "middle class" to describe my interlocutors' class belonging. The essence of this definition has however shifted with the years and today I would find it more appropriate to describe most of them as upper class individuals. For reasons of lack of space in this paper I will however not go into any further depth with this debate and stick to the notion of "middle class".

4. I highlight here my usage of the word "sanctioned" given that the India economy has been progressively opened up throughout history and in particular during the 80s under the prime ministership of Rajiv Gandhi.

5. This moment has been recently depicted by many authors (cf. Kamdar 2007, Taroor 2007, Gupta 2009).

6. This process proved the capacity of images to function as precious instruments for transcultural communication (cf. MacDougall 1998).

7. Delhi-ite is the conventional term used for defining an inhabitant of Delhi. 
8. These terms refer to the amount of focus contained by a single frame. Deep focus entails that almost all elements in a frame are visible while shallow focus entails that only a small portion of the image in sharp while the rest appears blurry to the eye.

9. Indeed, ethnographic film hosts a variety of different approaches to the use of voice-over. I contend however that voice-over is today quite dominant among anthropological filmmakers and in particular among the neophytes.

10. The "phantasm" was, in my usage, the 'instrument' through which my interlocutors approached, interpreted, felt and contextualized the images that surrounded them. Following Agamben (1993) who used the phantasm to describe what linked (and at the same time blurred the boundary between) the internal and the external, the real and the imaginary I approached the phantasm as what mediates not only between agents and their external space but also between the 'here' and 'there', the 'now' and 'then' of our daily experiences, between emotion and intellect, between collective and individual images, hence bringing together discourses and memories (in my case with different geographical and historical roots) that lie unspoken in our everyday lives (cf. also Ivy 1995).

11. If I were to do an episode two of FOD today I would probably use the mobile phones as key metaphors.

12. The camerawork of Angelo Fontana on this level was particularly important. Raised under the influence of Jean Rouch, Angelo never used tripods but would rather let the camera and his body explore together the objects of the film. I saw a great potentiality in this style of filming and asked him to push it forward by adding further movement to it, by using abrupt zooming-ins and zooming-outs, etc. In other words, I attempted at fusing, though his work, the style of Jean Rouch with that of MTV, ER, etc.

13. This is partly however an erroneous association given that the generation that was raised with MTV is the one probably coming right after that of my interlocutors.

14. As a consequence of this engagement, in the following years I devoted attention to the world of interactive documentaries (see Favero 2013).

15. I am presently working on incorporating FOD and the materials on Delhi that I have gathered during the past ten years into an interactive platform.

16. Andrew Lawrence has suggested that the act of filming ought to be viewed as a dance enacted together with the characters of the film.

\section{ABSTRACTS}

The present paper constitutes an exploration of the role of form and (visual) aesthetics in the construction and communication of ethnographic knowledge. It is based on the analysis of a documentary film entitled Flyoverdelhi (directed by the author of the article in 2004) that offers insights into the lives of young middle class men and women in Delhi at the dawn of India's emergence as a superpower. Reflecting upon the process of making, screening and then reanalyzing the film (15 years after its making), this paper discusses different dimensions of the dialogue between content and form/aesthetics in the context of ethnography. Despite its focus on film and visual communication, the paper aims at raising questions that are common to ethnographers and anthropologists at large and discusses also the relation between ethnographic validity and authority. The paper contains links to visual materials available online hence 
making a claim for the importance of renewing practcies of publishing in the contextx of visual anthropology.

Le présent article constitue une exploration du rôle de la forme et de l'esthétique (visuelle) dans la construction et la communication de la connaissance ethnographique. Il s'appuie sur l'analyse d'un film documentaire intitulé Flyoverdelhi (réalisé par l'auteur de l'article en 2004) qui offre un aperçu de la vie de jeunes hommes et de jeunes femmes de la classe moyenne à Delhi à l'aube de l'émergence de l'Inde comme superpuissance. Réfléchissant sur le processus de réalisation, de projection puis de ré-analyse du film (15 ans après sa réalisation), cet article aborde les différentes dimensions du dialogue entre contenu et forme / esthétique dans le cadre de l'ethnographie. Bien que centré sur le cinéma et la communication visuelle, l'article vise à soulever des questions communes aux ethnographes et aux anthropologues en général et traite également de la relation entre la validité ethnographique et celle de l'autorité. L'article comporte des liens vers des documents visuels disponibles en ligne, d'où l'importance de renouveler les pratiques d'édition dans le contexte de l'anthropologie visuelle.

El presente trabajo constituye una exploración del papel de la forma y la estética (visual) en la construcción y comunicación del conocimiento etnográfico. Se basa en el análisis de una película documental titulada Flyoverdelhi (dirigida por el autor del artículo en 2004) que ofrece información sobre las vidas de hombres y mujeres jóvenes de clase media en Delhi al comienzo de la emergencia de la India como superpotencia. Reflexionando sobre el proceso de realización, proyección y posteriormente re-análisis del film (15 años después de su realización), este documento analiza diferentes dimensiones del diálogo entre contenido y forma / estética en el contexto de la etnografía. A pesar de su enfoque en el cine y la comunicación visual, el artículo tiene como objetivo plantear cuestiones que son comunes para los etnógrafos y antropólogos en general, y analiza también la relación entre la validez etnográfica y la autoridad. El artículo contiene enlaces a materiales visuales disponibles en línea, reivindicando así la importancia de renovar las prácticas de publicación en el contexto de la antropología visual.

\section{INDEX}

Palabras claves: ethnographic film, anthropological film, visual ethnography, ethnographic practice, India, globalization, film analysis, cultural critique, editing, objectivity and the aesthetics of objectivity

Mots-clés: film ethnographique, film anthropologique, ethnographie visuelle, ethnographie, pratique ethnographique, Inde, mondialisation, analyse cinématographique, critique culturelle, montage, objectivité et esthétique de l'objectivité

Keywords: ethnographic film, anthropological film, visual ethnography, ethnographic practice, India, globalization, film analysis, cultural critique, editing, objectivity and the aesthetics of objectivity

\section{AUTHOR}

\section{PAOLO FAVERO}

University of Antwerp, Visual and Digital Cultures Research Center (ViDi)

paolo.favero@uantwerpen.be

Paolo Silvio Harald Favero is Associate Professor in Film Studies and Visual Culture at the

University of Antwerp. A visual anthropologist with a PhD from Stockholm University, Paolo has 
devoted the core of his career to the study of visual culture in India. Presently he conducts research on image-making, politics and technology in contemporary India as well as on questions of ontology and methodology in the context of emerging digital visual practices and technologies at global level. He is the author of the recent books "The Present Image: Visible Stories in a Digital Habitat (2018, Palgrave Macmillan). 